\title{
The Influence of Product Markets on Industrial Relations
}

\section{William Brown}

August 2006

CWPE 0652 


\title{
The Influence of Product Markets on Industrial Relations
}

\author{
William Brown \\ Faculty of Economics, University of Cambridge
}

\begin{abstract}
Product markets are the foundation on which industrial relations institutions are built. Trade union strength is partly dependent upon the state of the labour market, but it is imperfections in the product market that are the precondition of their winning benefits for their members. Sectoral agreements consequently formed the basis for collective bargaining in most industrialised countries. But international competition has destroyed this for much of the private sector. Quasi-markets have undermined it for much of the public sector. The paper assesses the empirical economic literature on the impact of product markets. It considers enthnographic insights into how competitive pressures feed through to managerial behaviour. It concludes with alternative strategies - co-operative bargaining, legislative intervention, and consumer campaigns - that seek to defend labour standards from competitive erosion.
\end{abstract}

Key words: product markets; John Commons; trade union power; collective bargaining; labour; wages; bargaining structure

JEL categories: B52; J01; J08; M54; N34.

This is to appear in the Handbook of Industrial Relations, edited by Blyton, P., Bacon, N., Fiorito, J., and Heery, E., Sage Handbook Series. The author is grateful for helpful comments from David Metcalf, Peter Nolan, Jon Trevor and the editors. 
Industrial relations are profoundly affected by the nature of the markets in which firms compete. The relationships between employers and workers cannot avoid being influenced by the competitive pressures bearing down on the employers, whether those pressures are light and permissive, or tight and unforgiving. How employers respond to these pressures is another matter. There may be many different ways of managing labour that allow firms to keep afloat in a given competitive situation. There will be consequent differences in their industrial relations. But whatever style of labour management is adopted, an important and unavoidable constraint on that style is whether, and with what urgency, the firm's business is under competitive threat.

This chapter is concerned with the relationship between industrial relations and the intensity of competition for a firm's goods and services - that is to say, the competitiveness of what is known generically as its 'product market'. The chapter considers first the development of bargaining structures, designed in large part to manage these competitive pressures. It explores how this has influenced trade unions because, as the labour economist Nickell has observed, 'what unions do depends upon what they can do, and this depends on the extent of product market competition' (Boeri et al., 2001; 296). Attention is also given to public sector employment that, despite its insulation from normal price mechanisms, is now heavily influenced by comparable constraints. The chapter next considers survey-based economic evidence of the link between industrial relations and product markets. It then focuses in to look at ethnographic case study evidence. This sheds light on how competitive pressures are translated into the varied patterns of managerial control or complacency under which great diversity of industrial relations has developed in different industries and at different times. Finally, it considers the impact of the geographical widening of product market competition in an increasingly international economy, and the implications of this for contemporary industrial relations institutions, which were rarely intended to reach beyond national frontiers.

\section{Competitive influences on bargaining structure}

Product markets have, in a world of more or less imperfect competition, always had a huge influence on bargaining structures. The reasons lie in the nature of trade union activity. Unions attract and retain members by negotiating and protecting improvements in their pay and conditions of work. They have traditionally done this either directly by using the threat of strike action, or by controlling the supply of labour. The consequence is that, if they are successful, and unless there are off-setting productivity improvements, they increase unit wage costs for the firms that employ their members. But this in turn implies that they reduce those firms' capacity to compete successfully in their product markets. So the organisational challenge facing unions is how to reduce the jeopardy in which members' jobs are placed as a result of increasing the cost of their labour.

The argument that this would be best met by unions' organising the whole product market was explored by the institutional economist John Commons. In 1909, in a study of the development of the American shoe industry, he drew attention to the historical emergence of a gap separating the wage bargain (between the employer and workers) from the price bargain (between the retailer and the consumer). 
Relationships between journeymen, masters and customers that, in a restricted local economy, had regulated not only wages, but also prices and quality, gave way to increasing domination by merchant retailers who fixed prices by reference to the cheapest labour market from which they could obtain substitute goods, wherever that might be. The employment standards of the local labour market become threatened by those of the relevant product market, however great its geographical extent. He described how what he called the 'competitive menace' is the marginal producer ' ....with the lowest standards of living and cost and quality of work, he is the producer whose competition tends to drag down the level of others toward his own' (Commons, 1964: 251).

'Throughout the course of industrial evolution the part played by the merchant stands out as the determining factor. The key to the situation is at all times the pricebargain,' Commons argues. 'It is the merchant who controls both capital and labor. If the merchant has a market, he can secure capital. The "conflict of capital and labor" is a conflict of market and labor, of merchant and wage-earner, of prices and wages.' (op. cit.: 261) Associations of manufacturers are primarily price-regarding. An extension of the product market, to include lower-paying marginal producers, is likely to provoke conflict, because established wage-earners may try to protect their wages through trade union action, When this happens, '...the manufacturer turns, for the time, from the market and faces the workman. His "employers' association” is wholly different in method, object and social significance, and usually in personnel from his "manufacturers' association”' (op. cit.: 262).

Power in industrial relations thus follows the contours of the markets for the goods and services produced, and not just the contours of the market for labour. It is not that the labour market is irrelevant. Indeed, the state of the labour market is of great importance to the relative power of employers and unions. Other things being equal, unions generally become stronger if the labour they organise becomes scarcer. But what they and employers have to fight over is decided by the employers' profits. They consequently do battle on a field delineated by the employers' product market.

The implications for unions are summarised by Kochan. He describes how Commons: 'showed that as transportation systems improved and it became feasible for employers to manufacture products in low labor cost cities and transport them to sell in high labor cost cities, it became necessary for unions to organise all competing employers in these various cities. The basic principle involved here is that unless unions organise all the substitutes for union labor, any increases in wage costs in the unionised portion of the market will result in a loss of employment to the non-union sector. Similarly, a strike by employees in the unionised sector will lead consumers to shift their demand to the non-union sector' (Kochan, 1980: 50).

Irrespective of whether labour is organised in trade unions, the management of it has been shaped by the predisposition of employers to see labour market issues as secondary to the price-driven pressures of the product market. Clegg notes that from very early on, many trade associations '...interfered with the laws of supply and demand on their own, even undertaking to regulate wages without any pressure from unions. This was true of both coal and iron. In coalmining the regulation of prices and wages on a county basis by the coal-owners was the general practice long before stable unions were established' (Clegg, 1970: 122). In the present, as in the past, employers constantly monitor their local labour markets to ensure their own firm's 
pay levels are sufficiently competitive to attract and retain workers. But they have a quite different concern with the cost implications of what their commercial competitors are paying, a concern which predisposes them, if possible, to 'take wages out of competition' by colluding with those competitors. It was Adam Smith who observed, well over two hundred years ago, that 'Masters are always and everywhere in a sort of tacit, but constant and uniform combination, not to raise wages of labour over their actual rate' (Smith, 1776: 59)

Thus, while it is in the interest of unions to organise all the workers in a given product market, the employers whom they confront are predisposed to collude with each other as product market competitors. They do this in order to bring stability to employment, which is always a sensitive and potentially volatile aspect of any firm's operations. It might seem surprising that there should be this congruence in employer and trade union organisational interests. But in practice it compounds into a broader collusion by both sides against the consumer of the product in question. Providing that all the employers in the product market are united, collectively they maintain a monopoly position which permits them to charge the consumer higher prices than would otherwise be the case. The resulting monopoly profits (referred to by economists as 'rents') may then, in effect, be shared with the union members by means of a collective agreement that establishes pay levels that are higher than would otherwise have been the case. This is where the state of the labour market and the organisational strength of the union become important; they influence what share of rents the union can win.

By combining against the consumer across the full extent of their product market, both sides benefit. The unions gain employer recognition and also relatively favourable, and stable, terms of employment for their members. Individual employers have the tricky problem of managing pay and conditions looked after by their employers' association. They are then free to concentrate on competing with each other by other means. Nor need such collusion be to the detriment of the consumer. By reinforcing training and other institutions at the industrial level, it can uphold quality standards for goods and services. It is likely to prevent a degrading 'race to the bottom' in employment conditions.

In Europe and some other countries, the result in due course was a remarkably stable organisational arrangement: the industrial agreement. Sometimes called a 'multiemployer' or 'sectoral' agreement, this became the foundation of collective bargaining in European industrialised countries for much of the $20^{\text {th }}$ century. Such arrangements often started on a local basis. Clegg notes that in Britain 'until the last quarter of the nineteenth century, most employers' associations were limited to a single town or region' (Clegg, 1970: 121). But they generally developed, in response to wider industrial conflict, and depending on the ease of transport of the product, to regional or national level. In his study of the cotton industry, Turner notes that such development tended to be more unstable when the employers had a strong cartel or monopoly element, 'but once it is clear that the unions are established, the employing body may move to a quite opposite attitude, of accommodation to collective organisation among its workers' (Turner, 1962: 378). And once such bargaining structures were established as the main means of fixing pay rates, working hours, holiday entitlements, and so on, they would typically become powerfully reinforced 
with their own distinct apprenticeship arrangements, dispute procedures and, in most European countries, legal support.

Despite the fact that these industrial agreements were technically in constraint of trade, they commanded considerable governmental support. In effect, government tolerated the restraint they placed on competition because of the benefits they offered in terms of industrial peace and good employment standards. From the late $19^{\text {th }}$ century onwards, industry-based collective bargaining was officially encouraged by British governments, typically as arrangements that were generally called National Joint Industrial Councils. In industries where unions were too weak for these, then the Wages Boards (later Wages Councils) were established, on the bases of the distinct product markets where labour exploitation was seen to be a problem - Coffin Furniture; Cotton Waste Reclamation; Keg and Drum manufacture; Lace Finishing, or whatever. As recently as 1961, the Ministry of Labour's official Industrial Relations Handbook could say:

'When the agreement is made by a number of different employers or, as is often the case, by an employers' association acting on behalf of the whole or the greater part of the firms in a given industry within a wide area, all the workers employed by the employers concerned are secured equality of treatment, while each employer is protected against unfair competition by reason of lower wages costs in so far as his competitors are parties to the agreement. For many years collective agreements have played a most important part in the regulation of working conditions in this country' (Ministry of Labour, 1961: 18).

In effect, European governments accepted the implied inefficiencies arising from this officially blessed, industry-wide collusion against the consumer, in return for the public benefits in terms of industrial peace, effective training management, and a raft of individual employment rights. In Britain there were adverse inflationary implications that first emerged in the late 1950s, exacerbated by declining productivity growth, but it was not until the late 1980s that government ministers were publicly to criticize industrial agreements as a source of inefficiency and uncompetitiveness. As a senior government minister, Kenneth Clarke, put it, in urging the abandonment of pay rises linked to industrial agreements: 'If we move to a system where pay increases are based primarily on performance, merit, company profitability, and demand and supply in the local labour market, we will dethrone once and for all the annual pay round and the belief that pay increases do not have to be earned' (Financial Times, $12^{\text {th }}$ February 1987).

The benefits of collusion in the product market as a basis for managing labour relations were substantial. Trade unions whose organisational logic was tied to a particular skill or occupation, rather than product market, (such as those based on craft) would accommodate to industrial collective bargaining by becoming, for these purposes alone, members of union federations, such as the Confederation of Shipbuilding and Engineering Unions. In industries characterised by considerable heterogeneity of product market - such as engineering - employers would exercise substantial discretion at workplace level but, on the key issues of basic wage rates and hours of work, they would follow the industrial agreement (Marsh, 1965: 176).

The grip of the industry agreement was usually tighter in industries characterised by homogeneity of production technique and product, such as the manufacture of hosiery, or ceramics, or carpets, or newspapers. Some employers' associations 
imposed considerable discipline, including the enforcement of lock-outs. In cotton, for instance, they fined mill owners who continued to run their mills when their association was in dispute with unions; they refused help to member firms who paid above or below agreed wage-rates; and as late as 1950, they expelled firms which paid unauthorised bonuses on wages (Turner, 1962: 377). Even today some continue to exercise discipline over their members, such as the association that organises electrical contractors for the construction industry, where licensing and safety issues are dominant.

Because labour can itself be so contentious and troublesome to manage, competing employers have a strong incentive to take it out of contention as an issue between themselves. Despite this, there have always been some employers who have pursued their own independent, enlightened employment practices as a distinctive means of product market competition. A number of Quaker-owned British firms come to mind that invested heavily in long-term relationships with employees and in their broader social welfare. Thereby they undoubtedly gained competitive advantage. But for most of the $19^{\text {th }}$ and $20^{\text {th }}$ centuries this sort of benign, employee-oriented independence remained very much more the exception than the rule (Donkin, 2001).

\section{The break up of product market based bargaining structure}

The starting point of this account of the underlying market dynamics of industrial relations was the predisposition of firms to concentrate, whether in competition or collusion, on the market in which their goods and services are traded. Wages are secondary to prices. If employees organise themselves into trade unions, sooner or later they have to come to terms with the employers' primary concern with the product market, and organise accordingly. As a consequence, firms' normal response, for most of the $20^{\text {th }}$ century, and for most developed economies (with the notable exception of the United States), was to confront the unions with employers' associations and to negotiate product market based, and hence industry based, collective agreements.

This was a satisfactory compromise so long as two conditions prevailed. The first was that the rival firms were sufficiently evenly matched within their product market, and gaining sufficiently from their collusion, for there to be inadequate net benefit to induce one or more larger firms to break away and deal with trade unions on their own (Ulman, 1974). The second condition was that trade unions were able to organise all relevant workers across the whole of the appropriate product market, in order to ensure that the firms they dealt with would not be undercut by competitors, able to gain advantage from employing cheaper labour.

The first condition prevailed in Europe, but it was not sustainable in Japan and the United States. European governments of the first part of the $20^{\text {th }}$ century generally provided substantial legislative support for industry-based collective bargaining and also often for the associated training arrangements, welfare and employment rights. In large part this was because these countries had political parties backed by trade unions, whose periods in government sustained this legal support. Thus both trade union security and employer solidarity received statutory support, and strong industrial agreements were a consequence. Japan and the United States, by contrast, not only lacked union-backed political parties with a commitment to collective bargaining, but had major industries that were, from early on, characterised by a 
relatively small number of dominant firms for which there were no net benefits from industry-based collective bargaining (Sisson, 1987).

In Europe, it was in Britain that industry-based bargaining first started to crumble. Initially this was because Britain's very laissez-faire legal structure provided little reinforcement to industrial bargaining and training institutions. These came under particular pressure when labour markets were tight in the 1950s and 1960s, creating exceptional strains between employers seeking to attract and retain scarce labour. One after another, industrial agreements began to break up, usually when a dominant employer felt that they would gain more by controlling their own industrial relations strategy, most commonly by improving the motivational power of their internal pay structure and by paying higher rates. Early examples were Cadbury leaving the confectionary makers, Dunlop leaving the rubber manufacturers, and Esso leaving the petroleum refiners (Brown and Terry, 1978: 130). Here we have cases of mainly labour market pressures causing the break-up of employer solidarity and hence of industrially based bargaining units. But this was happening firmly within the bounds of a secure national product market. By contrast, the second precondition is challenged by threats to the integrity of national product markets themselves.

The second precondition for industry-based collective bargaining is a trade union organisation that is sufficiently comprehensive to encompass the whole product market. As has been noted, the early expansion of product markets as transport improved within countries brought no insurmountable problems. Unions and employer associations connived to out-flank and match each other in expanding the geographic scope of collective agreements. But once agreements reached national frontiers this process of joint regulation stopped. Extending further was no problem for what Commons described as the 'merchant retailers'. They simply bought wherever abroad price and transport costs provided the cheapest package. Nor did expanding overseas necessarily impede the established national producers who, as the $20^{\text {th }}$ century drew to a close, increasingly outsourced abroad or became multi-national and established their own production facilities in cheap labour countries.

For trade unions, however, the challenge of incoming, cheaper product substitutes from beyond national frontiers has been severe and often insuperable. There is over a hundred years of history of attempts at international trade union co-operation. Ten industry-specific 'global union federations' are currently associated with the International Confederation of Free Trade Unions. They cover broad separate industrial areas such as transport, journalism, metalworking, and chemicals, energy and mining (Levinson, 1972). But whatever they contribute in terms of communication, lobbying, and the spread of good practice, there is no evidence that they have made a major contribution to the exercise of power in collective bargaining (Borgers, 2000; Cooke, 2005). Of the many obstacles that confront attempts to build international trade union solidarity, the greatest challenge is probably simply that of getting workers in one country to make sacrifices and worsen their own job prospects in defence of workers in another country whose jobs are under threat. Even in domestic disputes, collective action makes tough demands on worker altruism; the evidence is that such demands become unsustainable when extended across frontiers. International trade union co-operation can, through political action and consumer bans, play a part in inhibiting the irresponsible use of exploited labour in other countries. There has recently been some development of cross-frontier union co- 
operation within the European Union (Marginson and Sisson, 2004). But experience suggests that the international use of direct coercion by collective sanctions is not an available option.

The challenge facing trade unions is growing massively. Product markets have, in recent decades, become substantially more exposed to international competitive pressures. This is because the world economy has become steadily more open to trade. The annual growth of international trade since the last World War has been consistently higher than the annual growth in world output, and over the past 20 or so years has been twice as great. Quite apart from this relative growth of trade between nations, the number of major trading nations and the size of the world's competitive base have increased. The emergence of China, India, and the old Soviet nations as serious competitors since about 1990 has roughly doubled the worldwide reservoir of employees competing for jobs. These 'new' trading countries threaten exceptionally tough competition not only in terms of low wage rates but also, and of greater longterm significance, in terms of relatively high standards of education.

The internationalisation of product markets has also been increased by the internationalisation of company ownership. Foreign direct investment has over the past 20 years increased at twice the annual rate of world trade, facilitated by technological developments that have improved long-distance transport, communication, and control systems (Singh and Zammit, 2004; Acocella, 2005). The movement of jobs between countries, even while still within individual enterprises, becomes ever easier. Companies can easily move to sources of labour beyond the reach of both trade unions and legal employment protections.

From the trade union point of view, the prospects of gaining any effective bargaining leverage on ever more sprawling product markets are bleak. There have, of course, always been some unionised industrial sectors that have been exposed to foreign competition. A feature of the trade unions most affected is that they have often shown considerable sensitivity to this source of vulnerability. Thus, for example, in the 1960s and 1970s, the export-oriented metal-working unions took the lead in promoting counter-inflationary domestic economic policies in Germany, Switzerland and Australia (Crouch, 1993: 268; Kitaj and Lansbury, 1997: 225). But in the 20 century the challenge was often from unionised labour elsewhere, and in a relatively limited number of sectors of manufactures. More recently, international competition has intruded into an increasing range of both manufactures and services, and it has been much less constrained by trade unions, not least because their coverage has been diminishing in most countries. There are still some sheltered sectors. Unions are responding to the fact that many personal services are, by their nature, not amenable to overseas substitution, and thus offer substantial organisational potential (Milkman, 2004). But elsewhere they are finding ever fewer sectors tenable for effective industrial collective agreements.

In Britain this has been partly reflected in the steady contraction in the coverage of industrial (multi-employer) collective agreements as the main basis of pay fixing in the private sector. They had covered the majority of the private sector workforce in 1960. By 2004, however, industrial agreements covered only 4 per cent of private sector workers (in workplaces with 10 or more employees). Another 17 per cent of the workers in such workplaces were covered by enterprise-based (single-employer) 
agreements. But the remaining four fifths of the private sector workforce had lost the support of any collective bargaining whatsoever (Kersley et al, 2006: 186).

Product market circumstances have also influenced the manner of this radical restructuring of collective bargaining. A survey of UK multi-plant enterprises was conducted in 1985, at a time when industrial agreements were already in retreat, and when the single-employer bargaining, at that time to some extent replacing them, was close to its peak (Marginson et al., 1988). This confirmed that their adjustment was influenced by their exposure to international competition: '...it is employers whose companies compete primarily within the UK who appear to be most interested in taking wages 'out of competition' either on an intra-enterprise or an intra-industry basis.' (Marginson et al., 1988: 150).

Firms' internal arrangements are strongly influenced by their product markets. The survey by Marginson and his colleagues showed that, as employers withdrew from industrial agreements (whether or not they continued to recognise trade unions), they tended to restructure their internal pay-fixing arrangements along product market lines so that pay could be linked more directly to the performance of specific business units, whether profit centres, divisions, or individual establishments. As a result, for any particular establishment in one of these multi-plant companies, what tended to matter in terms of pay levels depended not on where the establishment was in the country geographically - that is, on its local labour market - but where it was situated in the business - that is, on its product market. Thus, even when divorced from collusion with their competitors, and when free to manage their own employment policies, employers remain focused primarily upon the demands of the market for their product, rather than the demands of the market for their labour.

\section{The use of proxy product markets in the public sector}

When we turn to the public sector, the influence of product markets on industrial relations was traditionally notable for its absence. This was simply because, operating in non-traded goods and services, these large and, in most countries, highly unionised industries were unconstrained by normal market forces. Their labour markets are distinctive because the employer is usually the dominant provider and purchaser of specialist skills - whether soldiering, teaching, nursing, fire-fighting, or whatever. Their product markets are even more aberrant because, quite apart from the absence of any price-fixing mechanism, questions of quality and distribution are by their nature politically determined. This tends to place trade unions in a strong bargaining position, although they have traditionally been reluctant (and in some countries legally unable) to use it. Pay is usually fixed by reference to external comparison with the private sector. 'Rent' is reflected in levels of job security, manning levels, and job control. If public sector employment were preserved in this isolation from the traded sector, its industrial relations would remain a very large 'special case' on the margins of the present discussion.

Product market change has, however, become a crucial issue for the public sectors of most western industrialised countries in recent years. In large part this has been because there has been widespread privatisation. For political, fiscal, strategic and economic reasons, a variety of usually highly unionised industries have been sold to the private sector. In Britain, this has included railways, bus transport, road haulage, telecommunications, docks, vehicle, aircraft and ship manufacture, steel, gas, water, 
electricity, coal, munitions, airlines, research laboratories, recruitment services, waste disposal, airports, publishing, and much else. For most of these, the transition, since the 1980s, to the demands of a more-or-less competitive product market was traumatic and often strike-ridden. In Australia, as in Britain, trade union membership has usually fallen substantially, and established patterns of job control and work organisation have been changed beyond recognition (Kitaj and Lansbury, 1997; Brown et al., 1998).

The chastening effect of the introduction of product market pressures on both trade union and managerial behaviour has had a substantial influence over British government policy towards those public services that have remained in state ownership. Since the 1980s, governments have introduced a number of devices to mimic or partially create similar stimuli. Those that introduced direct competition include: compulsory outsourcing of, and compulsory tendering for, non-core activities, such as catering and cleaning in hospitals and schools; building and highways maintenance for local government; pilot training for the armed forces; and prisoner transport for goals. One of the clearest examples where partial exposure to markets has had a fundamental impact on industrial relations was the creation, since the 1990s, of some privately owned and managed prisons. Covering about ten per cent of the British prison population at time of writing, the existence of these, and the threat of more, has permitted the relatively peaceful introduction of a number of procedural constraints on the use of collective action by previously often militant prison officers.

Much quasi-market intervention in Britain has been less direct. Throughout the health and education sectors, a proliferation of league tables and associated performance measures has been used to try to channel funds and users in ways that might stimulate efficient labour management. The civil service has seen its once monolithic pay structure broken up - mimicking private sector multi-divisional enterprises - into mock product market fragments reflecting the domains of different departments and agencies. The net effects of these changes across public services, in terms of efficiency and service delivery, remain highly controversial. Industrial relations have certainly become more overtly conflictual by comparison with the private sector. While public services accounted for a small minority of strike action until the 1990s, during the years 2000-05 they consistently accounted for at least a half of all strikes and three-quarters of all working days lost through strikes in the UK (ONS, 2006: 186). Some trade union opposition to quasi-market innovations has been successful. An example was the teachers' success in blunting the impact of performance-related pay in 1999. But generally the introduction of proxies for product markets has had the government's desired effect of diminishing the influence of public sector trade unions.

It was noted earlier that the condition of the labour market is of great importance to the relative power of employers and unions, but that they do battle on a field delineated by the employers' product market. It was also noted that the labour market for the public sector, which in Britain now largely means the public services, was highly constrained, with the state being the main provider and the main purchaser of the specialist skills required. This places the state, as employer, in a relatively weak position with regard to its employees, not least because of the political costs arising from the disruption of public services. The radical changes in public sector industrial relations of the past twenty or so years can be seen as a response to this. There has 
been a restructuring of incentives by the state in an effort to ensure, to use the previous metaphor, that power follows the contours of the market for the services delivered, not those of the market for labour delivering them, and thereby to rebuild the authority of the state as an employer.

\section{The economic evidence of product market effects}

In a perfectly competitive product market, the role of trade unions is highly constrained. They may engage in co-operative behaviour aimed at improving a firm's productivity. Sometimes called 'partnership' in Britain and 'mutual gains' in the United States, this has become more evident in the past decade in response to tighter competition. But any more confrontational action that succeeded in raising wages or improving work conditions without compensating productivity improvements may threaten the survival of the firm and its jobs by rendering it uncompetitive. Most product markets are, however, to varying extents, imperfectly competitive. The firms that operate successfully within them receive the resulting rents as monopoly profits. Whether trade unions are able to obtain a share of those rents, and thereby benefit their members, depends upon the organisational issues discussed earlier.

Even if unions cannot organise the whole product market, the degree of its imperfection has considerable bearing on their strategy. An imperfect product market implies that the individual firms operating in it have some monopoly power. This may arise, among other things, from a distinctive product, a good reputation for service, or a familiar brand-name. If unions can organise firms that have monopoly power, they should be able extract some of the rent as benefits for their members. Even if the firm is in such a competitive situation that there is no rent, or if there is rent but the union cannot mobilise the strength to bargain a share of it, the union may still maintain employer recognition and employee members through co-operative strategies that, for example, facilitate superior quality of service.

Similarly, in a perfect labour market, employees of like skills and other attributes would be paid the same, irrespective of the profitability of their employers. But in practice, labour markets are also imperfect. As we have seen, one reason for this is the active role that employers play in 'taking wages out of competition' in order to bring stability to labour management. But the ending of the collusive fixing of wages with industrial collective agreements does not end the manipulation of wages by employers. Employers when bereft of employers' associations do not necessarily become passive 'price takers'. For all but the smallest firms, or those dealing in transitory and relatively unskilled labour, employers remain, within fairly broad labour market constraints, active 'price makers'. But they do so with the objective of maximising the productivity of their labour. Internal pay structures are delicate motivational devices, whether or not they include performance-related pay and other explicit incentives. Notions of 'fair pay' are essentially concerned with relative pay, and the pay comparisons most intensely felt by workers arise within the enterprise. The demotivating consequences of internal pay mis-management can rapidly corrode labour productivity. Internal pay structures require constant management attention.

Once away from an industrial agreement, employers thus place great emphasis on the integrity of their firms' internal pay structures, adapting them to the particular needs of their businesses, while keeping a weather-eye on their local labour market pay levels in order to keep broadly in line with other employers. The effects of this were 
clearly demonstrated by a study of employees in seven occupations in 25 firms in the Coventry engineering industry over the decade of the 1970s, a watershed period in which these firms were breaking away from industrial collective bargaining into managing their own pay (Nolan and Brown, 1983). The study showed clearly how, as the decade progressed, the size of the annual pay rise an individual received owed less and less to their occupation, and more and more to the firm they were in. For the increasingly independent employers, in toughly competitive product markets, the labour market was a loose constraint. The important determinant of pay was '...the way in which employers manage work and pay so as to maximise their control over unit costs and output' (op. cit.: 284).

In Britain's private sector during the post-War years of relatively high trade union strength, employees' pay did generally reflect their firm's profitability (Carruth and Oswald, 1989: 166). But while this is consistent with a link between product market circumstances and industrial relations outcomes, it is far from sufficient evidence, because firms have many reasons for success other than the product market in which they are placed. One study that explored this further exploited the peculiar characteristics of Australia's wage-fixing system that made it possible to identify, by occupation and establishment, informal establishment-negotiated pay increases over and above the quasi-judicially established industrial rates (Brown, Hayles, Hughes and Rowe, 1984). The survey was conducted in 1974 of nearly 20,000 employees in 44 occupations in 198 establishments across nine industries in the urban labour market of Adelaide. The analysis suggested, as had the Coventry time-series study cited above, that pay settlements at establishment level owed more to the circumstances of the employer than to the occupation of the employee. More important, the analysis also suggested that the variance in the size of these establishment settlements correlated with the concentration ratio of the industry they were in. The less competitive was the industry, the less were the establishmentspecific determinants of pay. It was concluded that wages paid by individual employers in excess of the industrial rates could only partly be explained in terms of meeting the needs of the local labour market. They also appeared to reflect '...employers' efforts, within the bounds of their product market power, to construct internal pay structures that will placate their employees, and motivate them to work productively' (op. cit.: 175).

The influence of product markets is also reflected in the changing impact of collective bargaining. In a review of the micro-economic effects of trade unions, Metcalf notes that several studies in the 1980s had reported a negative association between union presence and financial performance. But by 1990 there were distinctive product market effects. Research suggested that 'over the course of the 1980s this negative impact weakened such that by 1990 the overall union effect was halved as compared to 1984 and unionised establishments had lower financial performance only where the union was strong and the establishment had some market power' (Wilkinson, 2000: 3). 'This tempering of the impact of unions was confirmed by Machin and Stewart (1996) who concluded that by 1990 unions only impacted adversely on profitability where there was a closed shop and/or weak competition in the product market' (Metcalf, 2003: 146).

'The intensity of competition has a profound effect on what unions can do...It is well known that non-competitive product markets permit unions to raise wages. But unions 
can capture product market rents in forms other than wages', observes Metcalf, citing their propensity to protect members by introducing rigidities in work organisation, rigidities which may incidently discourage innovation and thus productivity growth (op. cit.: 155). His own analysis of the 1998 British WERS (using over 1100 workplaces in the trading sector) permitted him to investigate this in unusual detail (controlling for a substantial number of workplace and workforce variables) because the survey contained comparative measures of labour productivity and of financial performance. When there is relatively low competition, with the firm reporting five or fewer competitors, 'the probability of above average labour productivity is 14 per cent lower for a unionised workplace than its non-union counterpart. But when there are six or more competitors the corresponding figure is 0.6 per cent (not statistically significant). And when there is little product market competition the likelihood of above average financial performance is 12.4 per cent lower for a union than nonunion workplace, yet the corresponding figure is 7.4 per cent higher with a more competitive product market' (op. cit.: 157). This is powerful evidence that product market competition plays a crucial role in determining union influence over both working practices and pay levels: the tighter the competition, the less the union influence.

The longer-term implications for trade unions are serious. Noting Blanchard's observation that across OECD countries 'rents are getting smaller, leading to less room for rent extraction ... this decrease in attractiveness [of unions to members] is reflected, in nearly all countries, by decreased membership and support' (Boeri et al., 2001: 295), Metcalf concludes that 'more intense product market competition implies a corrosion of the impact of union recognition in the workplace which suggests that in the longer term unions may need to find a different role if they are to prosper' (op. cit.: 157). It is a conclusion arrived at by the very different route of economic modelling of recent labour market performance in the United States and Europe by Ebell, Doppelhofer and Haefke (2004: 11) which concludes that the decline in unionisation in the US and UK might have been a direct consequence of product market reforms of the 1980s.

The picture that emerges from these quantitative studies is consistent with the earlier more descriptive account. As product markets become more internationally exposed, employers find it increasingly difficult to manage labour through employers' associations. If they cannot exercise control over wages by collusion with each other, they have the option of going alone, and making more active use of their payment systems as motivational devices. If employers' associations do break up, the ending of the industrial collective agreements associated with them has severe implications for trade union recognition. Bargaining may continue with employers on an individual basis, but its success is dependent upon the extent of those employers' monopoly power, as well as the union's organisational strength. Recent years have seen a reduction in trade unions' capacity to bargain a share of rents, both because those rents may have diminished and because unions are less able to mobilise effective bargaining power over geographically extended product markets. In the public services, the largely monopolistic and exclusively national nature of the product market ensures that the role of public employees' unions is relatively secure. But the scope for private sector trade unions in sectors exposed to foreign competition is becoming increasingly curtailed. 
The transmission of product market circumstances into workplace relations

Thus far this discussion has been concerned with the broad structures of industrial relations and how they are shaped by product market circumstances. But product markets also impact upon day-to-day industrial relations in a much more immediate way. By what means do product markets actually change behaviour and thereby shape the ways employers treat workers?

A study conducted in the heavy bargaining environment of the British engineering industry of the 1960s permitted a close examination of this question (Brown, 1973). The subject of enquiry was the individual piecework payment systems that were then prevalent in the industry. They were widely perceived to be a major cause of wage inflation through 'wage drift' processes that involved no formal negotiation. What were the origins of piecework pay rises, and why did their pace differ substantially between factories? Case studies of ten factories provided detailed individual wage data over several years, as well as opportunities for extensive interviews and observation. A close relationship was identified between the pace of informally derived piecework pay rises, on the one hand, and, on the other, the widely understood but unwritten, local workshop 'rules' that in effect regulated the informal bargaining over piecework 'prices'. These rules were not formally negotiated but developed as 'custom and practice'. This was primarily as a result of low-level managerial errors that, once accepted as desirable by workers, tended to become taken as binding precedents by their shop stewards and defended by threats of strike action. The relevant rules concerned questions such as the criteria for re-evaluating piecework prices, the appropriate level of compensation payment when machines broke down, and the restrictions placed on the managerial staff who set the prices.

What determined the leniency, from the pieceworker's point of view, of these 'custom and practice' rules? Two influences were identified. One was the slackness of management controls over work: over such matters as the recording of working time, the foreman's freedom to compensate for lost pieceworking time, and departmental cost controls. The other was the authority and coherence of the factories' shop stewards' committees, which had a potential role in controlling unruly bargaining that might jeopardise union solidarity. Both influences, the slackness of controls and the lack of authority of the shop steward organisation, were then shown to correlate with a composite measure of the constraints exercised by product market and technological factors.

The relevant conclusions drawn were, first, that the rules governing the bargaining process are '...heavily influenced by the control systems that managements see fit to install in their factories'. Second, that 'the principal pressures influencing management control systems are those of the product market, and different product markets can vary considerably in both the degree and the character of their competitiveness' (op. cit.:175). Third, that '...the organisational and bargaining characteristics of the workforce are not the root causes of poor management controls; a weakly integrated workforce may exacerbate the weaknesses of a control system further but it will have been the initial inadequacy of the controls which made the integration of the shop steward body difficult in the first place' (op. cit.: 171). And, finally, that '....under relatively full employment and trade union organisation, it is the product market rather than the labour market which has the major economic impact upon piecework wage determination' (op. cit.: 175). 
The chain of influence described here is fairly straight-forward. An uncompetitive product market does not directly cause poor management, but it does increase the probability of it because it provides an environment in which management has little incentive to devote resources to building and maintaining effective controls over labour and production. Sloppy controls give rise to inconsistency of payment and treatment of workers that generates discontents and encourages worker constraints on the organisation of work. Loss of control is manifest in many ways, and the firm unwittingly concedes to its workers much of the rent accruing from its partial monopoly position. For the workers, the rent they thereby gain takes various largely haphazard forms: inequitably distributed 'windfall' pay rises, substantial control over the pace and conduct of work, discretion over job mobility, control over overtime, and so on. A loss of focus on competition in the product market leads to a loss of control over the management of the labour market.

The post-War British engineering industry was far from unique in this response to weak product market competition. Other major industries have seen similar development of haphazard workplace rent sharing arising from weak managerial controls. This was perhaps most notable in the decade or so of slack competition that followed the devastation of potential overseas competitors during the Second World War. Thus the docks industry saw its workforce develop diverse localised controls over manning, piecework, and work allocation (Mellish, 1972). National newspapers allowed their union chapels to exercise almost complete control over work patterns, overtime and manning levels, a level of restriction that must have provided a barrier to new entrants from which the owners probably benefited (Sisson, 1975). The petroleum refining and distribution industry allowed middle managers repeatedly to concede aspects of the management of overtime to local union branches (Flanders, 1964; Ahlstrand, 1990). One could go on. A lack of financial restraint on employers is often associated with poor labour management - the stable lads employed by racehorse trainers and the household staff of British royalty provide well-documented examples - because the employer has little financial incentive to respond positively to the needs and capabilities of employees.

The more recent history of British industrial relations has been dominated by varied responses to tightening product markets. For some whole industries the shock has been so great, and the response so inadequate, that they have contracted almost to the point of vanishing in the face of overseas competition - coal-mining, ceramics, shipbuilding, footwear, textiles and clothing are examples. Some companies have responded by derecognising unions, sometimes also out-sourcing work to non-union organisations - television, facilities management, newspapers, and banking provide examples. A common response has been to maintain formal union recognition but implicitly to reduce it substantially by reducing both the range of issues subject to negotiation and the influence that unions can have over them (Brown et al., 1998; Brown et al., 2000). Increasingly this has been combined with explicit co-operative bargaining arrangements (Oxenbridge and Brown, 2002). In all cases the primary driver for change has been heightened product market competition, and an accompanying feature has been a much-weakened trade union, less capable of accessing rents for its members other than through co-operative strategies. 


\section{Conclusion}

This chapter has argued that product markets form the foundation upon which industrial relations institutions are built. Trade union strength with respect to employers is, of course, much affected by the tightness of the labour market, whether that arises from an economic boom, or from effective union controls over labour supply, or whatever else. But it is pre-existing imperfections in the product market that permit collective bargaining to deliver benefits to workers. The greater the imperfections, the greater the scope for union members to benefit, provided their union can exercise effective leverage over all suppliers to the product market, or over individual employers who occupy a sufficiently monopolistic position within it.

It has been argued here that the configuration of product markets has been moving in ways that are increasingly adverse for collective bargaining. This is of less significance in the public sector. Although even there the state has been eroding the bargaining position of public sector trade unions by mimicking product market incentives in order to weaken the employers' focus on labour. But the changing nature of product markets is of deep significance for the private sector, where so much employment is now exposed to competition from parts of the world where neither trade unions nor statutory minimum labour standards offer significant constraints.

Denied effective coercive bargaining power because of tighter product market competition, trade unions in many sectors are obliged to focus increasingly on strategies which in the past have tended to augment, rather than replace, confrontational bargaining. One of these is co-operative working with employers through the arrangements sometimes referred to as 'partnership' and 'mutual gains'. The success of this depends very much upon the willingness of the employer to make it effective and to encourage trade union membership as a means of upholding good employment practice.

Another strategy that is well-established in Europe is that of lobbying the government to improve statutory support for employment standards. Legal enforcement of improved terms and conditions is directly important to union members as to any other employees. It is also establishes a floor on which collective bargaining can build without fear of being seriously under-cut. The improvement of statutory rights such as minimum wages and maximum working hours is of particular importance to unions seeking to organise those large numbers of workers in the private services where international competition does not pose a threat. A major stimulus since the 1970s has come from the European Union, but the addition of poorer new member states of Eastern Europe will slow this down.

A third strategy, aimed at tackling the huge difficulties raised by the globalisation of product markets, is that of consumer campaigns, whereby adverse publicity is given to those brand names which use suppliers with poor labour standards. During the past decade such campaigns have prompted a substantial increase in the use of publicly reported 'ethical trading audits' by both major consumer good brand names and major supermarket chains. The challenge such campaigns face is formidable. Because trading enterprises steer by the commercial imperatives of their product markets then, to the extent that their markets are global, the standards of employment for increasing numbers of workers will tend to be dragged down by the depth of inequality of labour across the world economy. The campaigners have to counter this by appealing to the 
consciences of consumers, and thereby threatening the reputation of the brand names and supermarkets. It is a vivid vindication of John Commons' emphasis, a hundred years ago, on the pivotal role of the 'merchant retailer'.

This chapter has been concerned with the interaction of markets and institutions. A major role of trade unions has always been to build institutions to provide the agreements and other protections that might insulate their members from the harsh vagaries of the market for their labour. Such vagaries have, in turn, depended heavily upon the markets for the goods and services that their labour produced. Ensuring that the geographic reach of union organisation equalled that of their members' labour markets was relatively straight-forward. Doing the same for their employers' product markets was more difficult. But it suited the employers' own desire to remove employment as an issue of competitive contention and, with state support, provided the basis for nationally based employment regulation for many countries for most of the $20^{\text {th }}$ century.

Collective bargaining, and national statutory labour standards, tamed labour markets so long as product markets were predominantly nation-based. It has been the increasingly international nature of the world economy that has thrown these systems into disarray. Product markets that extend beyond the reach of either union movements or national governments now threaten the security and well-being of workers world-wide. The challenge for the $21^{\text {st }}$ century is to develop new international institutions, capable of protecting decent labour standards and of diminishing the inequalities that will otherwise destroy them.

\section{Acknowledgements}

The author is grateful for helpful comments from David Metcalf, Peter Nolan, Jon Trevor and the editors.

\section{$\underline{\text { References }}$}

Acocella, N. (2005), Economic Policy in the Age of Globalisation, Cambridge: CUP.

Ahlstrand, B. (1990), The Quest for Productivity, Cambridge: CUP.

Boeri, T., Brugiavivi, A. and Clamfors, L. (eds), (2001), The Role of Unions in the Twenty-First Century, Oxford: OUP.

Borgers, F. (2000), 'Global unionism: organisational challenges', in Hanami, T. (ed.), Universal Wisdom through Globalisation, Tokyo: Japan Institute of Labour.

Brown, W. (1973), Piecework Bargaining, London: Heinemann.

Brown, W. and Terry, M. (1978), 'The changing nature of national wage agreements', Scottish Journal of Political Economy, 25:2, pp119 - 134. 
Brown, W., Hayles, J., Hughes, B., and Rowe, L. (1984), 'Product and labour markets in wage determination: some Australian evidence', British Journal of Industrial Relations, XXII:2, pp169-176.

Brown, W., Deakin, S., Hudson, M., Pratten, C., and Ryan, P. (1998), The Individualisation of Employment Contracts in Britain, London: DTI

Brown, W., Deakin, S., Nash, D., and Oxenbridge, S. (2000), 'The employment contract: from collective procedures to individual rights', British Journal of Industrial Relations, 38:4, $611-630$.

Carruth, A. A. and Oswald, A. J. (1989), Pay Determination and Industrial Prosperity, Oxford: Clarendon Press.

Commons, J. R. (1964), 'American Shoemakers, 1648-1895: A Sketch of Industrial Evolution', Labor and Administration, A. M. Kelley: New York, reprinted from Quarterly Journal of Economics, November, 1909.

Cooke, W. N. (2005), 'Exercising power in a prisoner's dilemma: transnational collective bargaining in an era of corporate globalisation?', Industrial Relations Journal, 36:4, pp283 - 302.

Crouch, C. (1993), Industrial Relations and European State Traditions, Oxford: Clarendon.

Donkin, R. (2001), Blood, Sweat and Tears: the Evolution of Work, New York: Texere.

Ebell, M., Doppelhofer, G., and Haefke, C. (2004), 'Product market regulation in the presence of unions: quantitative implications', Discussion paper?

Flanders, A. (1964), The Fawley Productivity Agreements, London: Faber and Faber

Kersley, B., Alpin, C., Forth, J., Bryson, A., Bewley, H., Dix, G., and Oxenbridge, S. (2006), Inside the Workplace: Findings from the 2004 Workplace Employment Relations Survey, London: Routledge.

Kitaj, J. and Lansbury, R. (1997), Changing Employment Relations in Australia, Oxford: OUP.

Kochan, T. (1980), Collective Bargaining and Industrial Relations, R. D. Homewood: Irwin.

Levinson, C. (1972), International Trade Unionism, London: Allen and Unwin.

Machin, S. and Stewart, M. (1996), Trade unions and financial performance', Oxford Economic Papers, 48 (2), 213 - 241. 
Marginson, P., Edwards, P. K., Martin, R., Purcell, J., and Sisson, K. (1988), Beyond the Workplace: Managing Industrial Relations in the Multi-Establishment Enterprise, Oxford: Blackwell.

Marginson, P. and Sisson, K. (2004), European Integration and Industrial Relations, Basingstoke: Palgrave.

Marsh, A. (1965), Industrial Relations in Engineering, Oxford: Pergamon.

Mellish, M. (1972), The Docks after Devlin, London: Heinemann

Metcalf, D. (2003), 'Unions and productivity, financial performance and investment: international evidence', in Addison, J. T. and Schnabel, C. (eds), International Handbook of Trade Unions, Cheltenham: Elgar

Milkman, R. (2004), Organising Immigrants in California, Cornell: ILR Press.

Ministry of Labour (1961), Industrial Relations Handbook, London: HMSO.

Nolan, P. and Brown, W. (1983), 'Competition and workplace wage determination', Oxford Bulletin of Economics and Statistics, 45:3, 269 - 288.

Office for National Statistics (2006), 'Labour disputes in 2005', Labour Market Trends, Vol 114, No 6, pp174-190.

Oxenbridge, S. and Brown, W. (2002), 'The two faces of partnership? An assessment of partnership and co-operative employer/trade union relationships', Employee Relations, 24:3, $262-276$.

Singh, A. and Zammit, A. (2004), 'Labour standards and the 'race to the bottom': rethinking globalization and workers' rights from developmental and solidaristic perspectives', Oxford Review of Economic Policy, 20:1.

Sisson, K. (1975), Industrial Relations in Fleet Street, Oxford: Blackwell.

Sisson, K. (1987), The Management of Collective Bargaining, Oxford: Blackwell

Smith, A. (1776), The Wealth of Nations, London: Strahan and Cadell.

Turner, H. A. (1962), Trade Union Growth, Structure and Policy, London: Allen \& Unwin.

Ulman, L. (1974), 'Connective bargaining and competitive bargaining', Scottish Journal of Political Economy, XXI.

Wilkinson, D. (2000), 'Collective bargaining and workplace financial performance in Britain’, mimeo, Policy Studies Institute, April. 